Hydraulic Engineering Repository

Ein Service der Bundesanstalt für Wasserbau

Perlea, Vlad; Mathews, David; Walberg, Francke

Modeling Erosion of an Unlined Spillway Chute Cut in Rock

Verfügbar unter / Available at:

https://hdl.handle.net/20.500.11970/100271

Vorgeschlagene Zitierweise / Suggested citation:

Perlea, Vlad; Mathews, David; Walberg, Francke (2010): Modeling Erosion of an Unlined Spillway Chute Cut in Rock. In: Burns, Susan E.; Bhatia, Shobha K.; Avila, Catherine M. C.; Hunt, Beatrice E. (Hg.):

Proceedings 5th International Conference on Scour and Erosion (ICSE-5), November 7-10, 2010, San Francisco, USA. Reston, Va.: American Society of Civil Engineers. S. 530-539. 


\title{
Modeling Erosion of an Unlined Spillway Chute Cut in Rock
}

\author{
Vlad Perlea ${ }^{1}$, M. ASCE, Ph.D., P.E., David Mathews ${ }^{2}$, M. ASCE, P.E., and Francke \\ Walberg $^{3}$, M. ASCE, P.E.
}

${ }^{1}$ U.S. Army Corps of Engineers, Sacramento District, 1325 J Street, Sacramento, CA 95814; PH (916) 557-5320; email: vlad.g.perlea@usace.army.mil

${ }^{2}$ U.S. Army Corps of Engineers, Kansas City District, 601 E $12^{\text {th }}$ Street, Kansas City, MO 64106; PH (816) 389-3696; email: david.l.mathews àusace.army.mil

${ }^{3}$ URS Corporation, 8300 College Blvd., Suite 200, Overland Park, KS 66210; PH (913) 344-1120; email: francke walberg/a urscorp.com

\begin{abstract}
Discharges up to $1700 \mathrm{~m}^{3} / \mathrm{s}$ that lasted 21 days caused extensive erosion of the spillway chute excavated in rock at Tuttle Creek Lake, Kansas. Nearly $300000 \mathrm{~m}^{3}$ of shale and limestone were eroded from the unlined chute resulting in a series of escarpments ranging in height from 1.20 to about $8 \mathrm{~m}$. An empirical mathematical model, similar to a US Department of Agriculture model was developed for geologic conditions at Tuttle Creek Lake. This site specific model was used to evaluate the extent of erosion anticipated for future events and, based on this evaluation, to design the spillway repair. The model provides conservative results since it was conceived in such a manner as to over predict erosion. Initial attempts to generalize its use provided questionable results, but similar site specific procedures may be used in other locations for future events.
\end{abstract}

\section{INTRODUCTION}

A recent report by U.S. Society on Dams, Committee on Hydraulics of Dams (USSD 2006) identifies three major types of progression mechanisms of unlined spillways erosion:

- Headcut erosion, that occurs mainly in soils and sedimentary rocks, as present in Midwest United States; examples are Tuttle Creek spillway, Kansas, Milford spillway, Kansas, and Saylorville spillway, Iowa.

- Pothole scour, observed mainly in volcanic rock formations; an example is Painted Rock spillway, Arizona.

- Plunge pool scour, which may occur in any type of rock; a typical example is Bartlett spillway, Arizona, cut in granite.

This paper deals with the first category only and it is focused on the Tuttle Creek spillway case history, which apparently is the best documented case of headcut erosion.

\section{TUTTLE CREEK SPILLWAY EROSION}

\section{Project and erosion event general descriptions}

Tuttle Creek reservoir is a U.S. Army Corps of Engineers (USACE) Kansas City District (KCD) flood control project located in Eastern Kansas. It has a 24937 $\mathrm{km}^{2}$ watershed and an estimated maximum design outflow through the controlled 
chute spillway of $17320 \mathrm{~m}^{3} / \mathrm{s}$. The dam, designed and constructed in the 1950's, is a rolled-earth/rock fill embankment about $43 \mathrm{~m}$ high and $2286 \mathrm{~m}$ in length. The spillway is located on the left abutment of the dam and consists of a concrete weir structure and an unlined chute. The weir structure is $256 \mathrm{~m}$ wide with 18 tainter gates $6 \mathrm{~m}$ high and non-overflow bulkheads. A reinforced concrete apron is as wide as the weir, $183 \mathrm{~m}$ in length and terminates with a flip bucket which includes a cutoff wall. Figure 1 shows an aerial photo of the spillway taken a short time after the erosion occurrence.

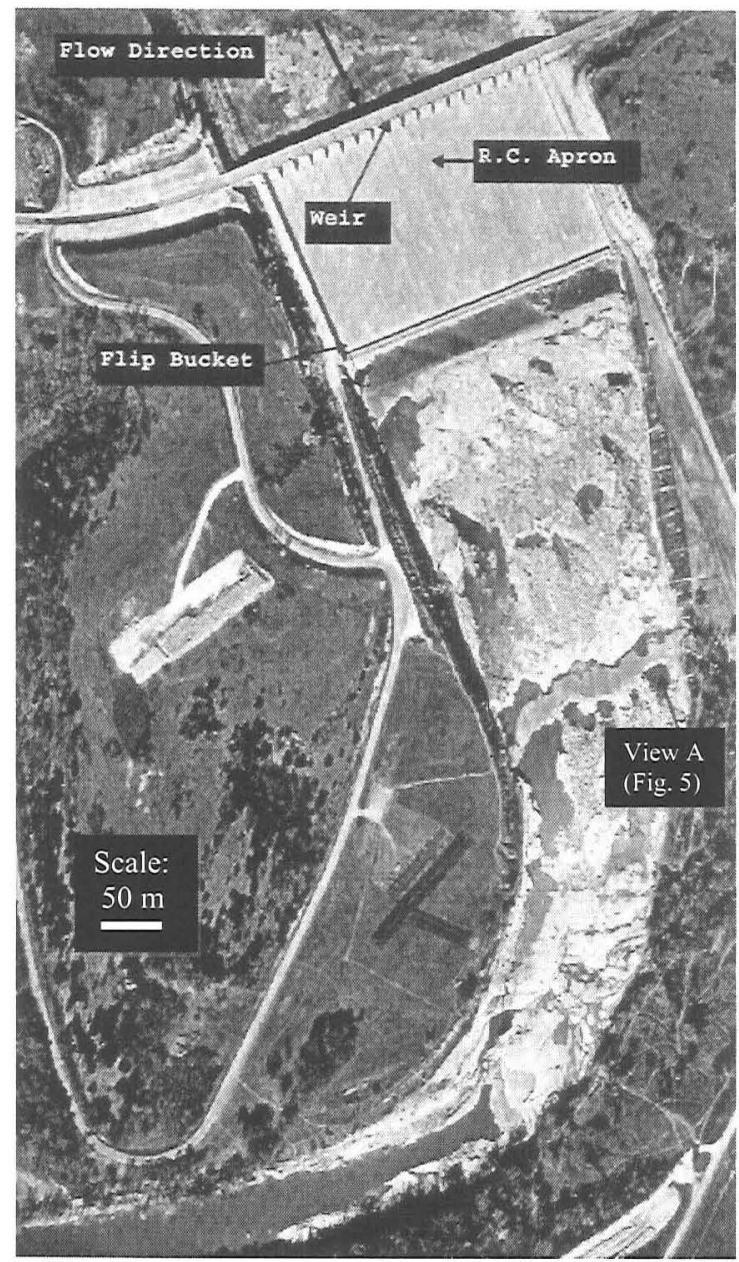

Figure 1. Post-erosion aerial photo of Tuttle Creek spillway. 
The unlined chute was excavated $256 \mathrm{~m}$ wide at the flip bucket and narrows to only $61 \mathrm{~m}$ wide at the lower end. The chute drops over $26 \mathrm{~m}$ in elevation in a horizontal distance of $1036 \mathrm{~m}$. The average channel gradient is approximately 2.5 $\%$. The chute is not straight but curves $90^{\circ}$ to the right. The excavation encounters alternating limestone and shale units of variable thicknesses (see Table 1). The layers dip approximately 1 degree in the opposite direction as the channel bottom slope. The major limestone units are relatively durable and do not erode easily, however the shale units are generally soft and erodible. The unlined chute is susceptible to head cutting because erosion of the shales results in undermining of the erosion resistant limestones.

A major flood event, with an estimated 100-year return period, occurred in the summer of 1993. Discharges through the spillway occurred for the first time, after 30 years of operation of the project. Spillway releases lasted 21 days reaching a peak discharge of $1700 \mathrm{~m}^{3} / \mathrm{s}$. Nearly $300000 \mathrm{~m}^{3}$ of material were eroded resulting in a series of escarpments ranging in height from $1.20 \mathrm{~m}$ to about $8 \mathrm{~m}$ with some concentrated head cuttings. The design hydrograph, based on an estimated peak inflow of $22640 \mathrm{~m}^{3} / \mathrm{s}$, has the peak outflow of $17320 \mathrm{~m}^{3} / \mathrm{s}$ (ten times greater than the 1993 flood event) and a duration of about 11 days (compared to 21 days in 1993). While this event was used for establishing the required size of the spillway, it should be understood that it may or may not be critical with respect to the assessment of the extent of erosion. The possibility of long duration events with smaller peak discharges must also be considered. In this respect, a model was developed to project anticipated erosion over the full range of discharges, based on site specific data from the 1993 spillway release and data from literature.

\section{Area geology}

The site geology is characterized by alternating layers of limestone and shale. The limestones are medium hard to hard and the shales are generally soft and laminated. Table 1 shows the simplified geologic column of the rock units encountered in the spillway.

The characterization of the rock units for hydraulic erodibility was made in accordance with the methodology developed at U.S. Department of Agriculture (USDA) by John Moore and Darrel Temple (Moore et al. 1994, USDA 1997).

\section{Rock erodibility characterization}

According to Moore et al. (1994) the spillway erosion process can be divided in three sequential phases for purposes of mathematical quantification:

- Phase I: Erosion resulting in the local failure of the vegetal cover, if any, and the development of the concentrated flow;

- Phase II: The downward and downstream erosion leading to the formation of a vertical or near vertical headcut, and

- Phase III: The upstream advance of the headcut with associated widening and deepening of the eroded volume.

In the case of Tuttle Creek spillway it is believed that the first two phases had a relatively short duration as compared with the third phase. Measurements of the headcut advance that were used in development and calibration of an erosion model 
became available starting with the sixth day of discharge, when the erosion process was evidently in the third phase of development all along the unlined portion of the spillway. Therefore, only phase III parameters were evaluated and used in mathematical quantification of the spillway erosion.

Table 1. Geologic Column

\begin{tabular}{|c|c|c|c|c|c|c|c|}
\hline \multirow{2}{*}{ Rock Unit } & \multirow[t]{2}{*}{$\begin{array}{l}\text { Rock } \\
\text { Type }\end{array}$} & \multirow{2}{*}{$\begin{array}{c}\text { Layer } \\
\text { Thickness } \\
(\mathrm{m})\end{array}$} & \multirow{2}{*}{$\begin{array}{l}\text { Headcut } \\
\text { Height } \\
\text { (m) }\end{array}$} & \multicolumn{4}{|c|}{$\begin{array}{l}\text { Characteristic Parameters for } \\
\text { Defining the Erodibility Index }\end{array}$} \\
\hline & & & & $\mathrm{UCS}(\mathrm{MPa})$ & $\mathrm{J}_{\mathrm{n}}$ & RQD & $\mathrm{J}_{\mathrm{a}, \max }$ \\
\hline $\begin{array}{l}\text { Burr } \\
\text { Legion }\end{array}$ & $\begin{array}{l}\text { Limestone } \\
\text { Shale }\end{array}$ & $\begin{array}{l}1.20 \\
0.60\end{array}$ & $\begin{array}{c}1.80 \\
(\text { No.1) }\end{array}$ & \multicolumn{4}{|c|}{$\begin{array}{c}\text { These geologic units were } \\
\text { completely washed out }\end{array}$} \\
\hline \multirow{2}{*}{$\begin{array}{l}\text { Sallyards } \\
\text { Roca, Zone A }\end{array}$} & \multirow{2}{*}{$\begin{array}{l}\text { Limestone } \\
\text { Shale }\end{array}$} & 0.60 & \multirow{2}{*}{$\begin{array}{c}1.90 \\
\text { (No.2) }\end{array}$} & 27.0 & 2.2 & 79.3 & 2 \\
\hline & & 1.30 & & 2.5 & 5.0 & $20 *$ & 4 \\
\hline \multirow{2}{*}{$\begin{array}{l}\text { Roca, Zone B } \\
\text { Roca, Zone C }\end{array}$} & \multirow{2}{*}{$\begin{array}{l}\text { Limestone } \\
\text { Shale }\end{array}$} & 0.30 & \multirow{2}{*}{$\begin{array}{c}1,20 \\
(\text { No.3) }\end{array}$} & 17.1 & 3.3 & 89.3 & 2 \\
\hline & & 0.90 & & 5.9 & 5.0 & $15 *$ & 6 \\
\hline \multirow{6}{*}{$\begin{array}{l}\text { Roca, Zone D } \\
\text { Roca, Zone E } \\
\text { Roca, Zone F } \\
\text { Roca, Zone G } \\
\text { Roca, Zone H } \\
\text { Roca, Zone I }\end{array}$} & \multirow{6}{*}{$\begin{array}{l}\text { Limestone } \\
\text { Shale } \\
\text { Limestone } \\
\text { Shale } \\
\text { Limestone } \\
\text { Shale }\end{array}$} & \multirow{6}{*}{$\begin{array}{l}0.50 \\
1.50 \\
0.35 \\
0.70 \\
0.40 \\
1.10\end{array}$} & \multirow{6}{*}{$\begin{array}{c}4.55 \\
\text { (No.4) }\end{array}$} & 10.9 & 5.0 & $50 *$ & 4 \\
\hline & & & & 11.4 & 5.0 & $40 *$ & 4 \\
\hline & & & & 7.4 & 5.0 & $25^{*}$ & 4 \\
\hline & & & & 5.7 & 5.0 & $40 *$ & 4 \\
\hline & & & & 6.8 & 3.3 & 71.0 & 2 \\
\hline & & & & 5.3 & 5.0 & $40 *$ & 4 \\
\hline \multirow{2}{*}{$\begin{array}{l}\text { Howe } \\
\text { Bennett }\end{array}$} & \multirow{2}{*}{$\begin{array}{l}\text { Limestone } \\
\text { Shale }\end{array}$} & \multirow{2}{*}{$\begin{array}{l}1.25 \\
1.05\end{array}$} & \multirow{2}{*}{$\begin{array}{c}2.30 \\
(\text { No.5) }\end{array}$} & 19.6 & 3.3 & 94.0 & 2 \\
\hline & & & & 1.7 & 5.0 & $15 *$ & 6 \\
\hline \multirow{2}{*}{$\begin{array}{l}\text { Glenrock } \\
\text { Johnson, Zone A }\end{array}$} & \multirow{2}{*}{$\begin{array}{l}\text { Limestone } \\
\text { Shale }\end{array}$} & \multirow{2}{*}{$\begin{array}{l}0.80 \\
2.40 \\
\end{array}$} & \multirow{6}{*}{$\begin{array}{l}8.00 \\
\text { (Nos. } \\
6 \& 7 \text { ) }\end{array}$} & 45.7 & 2.7 & 95.0 & 2 \\
\hline & & & & 2.3 & 5.0 & $30 *$ & 4 \\
\hline \multirow{4}{*}{$\begin{array}{l}\text { Johnson, Zone B } \\
\text { Johnson, C\&D } \\
\text { Johnson, Zone E } \\
\text { Johnson, F\&G }\end{array}$} & \multirow{4}{*}{$\begin{array}{l}\text { Limestone } \\
\text { Shale } \\
\text { Shale } \\
\text { Shale }\end{array}$} & \multirow{4}{*}{$\begin{array}{l}0.60 \\
2.10 \\
0.60 \\
1.50\end{array}$} & & 25.0 & 3.3 & $60 *$ & 4 \\
\hline & & & & 6.7 & 5.0 & $45^{*}$ & 4 \\
\hline & & & & 8.4 & 5.0 & $50 *$ & 4 \\
\hline & & & & 2.5 & 5.0 & $30 *$ & 4 \\
\hline \multirow{3}{*}{$\begin{array}{l}\text { Long Creek, A } \\
\text { Zones B\&C } \\
\text { Hughes Creek, A }\end{array}$} & \multirow{3}{*}{$\begin{array}{l}\text { Limestone } \\
\text { Limestone } \\
\text { Shale }\end{array}$} & \multirow{3}{*}{$\begin{array}{l}0.90 \\
2.15 \\
1.00\end{array}$} & \multirow{3}{*}{$\begin{array}{c}4.05 \\
\text { (No.8) }\end{array}$} & 28.3 & 3.3 & 91.1 & 2 \\
\hline & & & & 20.4 & 3.3 & 90.0 & 2 \\
\hline & & & & 12.4 & 3.3 & $40 *$ & 2 \\
\hline Zone B & Limestone & 0.80 & 3.00 & 26.6 & 3.3 & $70 *$ & 3 \\
\hline Zones C\&D & Shale & 2.20 & & 6.4 & 3.3 & $40 *$ & 2 \\
\hline Zone E & Limestone & 0.60 & 1.70 & 23.8 & 3.3 & $50 *$ & 3 \\
\hline Zone $\mathrm{F}$ & Shale & 1.10 & & 9.6 & 3.3 & $40 *$ & 3 \\
\hline
\end{tabular}

Notes: * Estimated values. Symbol definition (UCS, $\mathrm{J}_{\mathrm{n}}, \mathrm{RQD}, \mathrm{J}_{\mathrm{a}, \max }$ ) are given below.

According to Moore et al. (1994) the erodibility index (previously defined as excavatability index by Kirsten, 1982), $\mathrm{K}_{\mathrm{h}}$, represents a measure of the resistance of the material to erosion and has the general form:

where:

$$
\mathrm{K}_{\mathrm{h}}=\mathrm{M}_{\mathrm{s}} \cdot \mathrm{K}_{\mathrm{b}} \cdot \mathrm{K}_{\mathrm{d}} \cdot \mathrm{J}_{\mathrm{s}}
$$


$\mathrm{M}_{\mathrm{s}}=$ material strength number of the earth/rock material. For rock, $\mathrm{M}_{\mathrm{s}}=0.78$ - $(\text { UCS })^{1.09}$ for UCS $\leq 10 \mathrm{MPa}$ and $\mathrm{M}_{\mathrm{s}}=\mathrm{UCS}$ for UCS $>10 \mathrm{MPa}$, where UCS is the unconfined compressive strength (ASTM D 2938). The UCS values resulted from laboratory tests on specimens taken from borings drilled in Tuttle Creek spillway are listed in Table 1.

$\mathrm{K}_{\mathrm{b}}=$ block/particle size number. For fractured rock and rock-like materials the primary method of calculation of this parameter is $K_{b}=R Q D / J_{n}$ where RQD = Rock Quality Designation and $\mathrm{J}_{\mathrm{n}}=$ joint set number. RQD is a standard parameter in drill core logging and represents the sum of the length of the core pieces greater than $0.1 \mathrm{~m}$ divided by the total core run length (usually $1.5 \mathrm{~m}$ ), expressed in percent. $\mathrm{J}_{\mathrm{n}}$ is a scale factor representing the effect of different individual discontinuity spacings relative to the average discontinuity spacing; this factor accounts for the shape of the material units or, alternatively, the relative occurrence of different joint sets. For selection of the values listed in Table 1 detailed (unpublished) recommendations by Moore were considered; these recommendations are currently available in USDA, 1997.

$\mathrm{K}_{\mathrm{d}}=$ discontinuity/inter-particle bond shear strength number. $\mathrm{K}_{\mathrm{d}}=\mathrm{J}_{\mathrm{r}} / \mathrm{J}_{\mathrm{a}}$ where $\mathrm{J}_{\mathrm{r}}=$ joint roughness number, which represents the degree of roughness of opposing faces of a rock discontinuity, and $\mathrm{J}_{\mathrm{a}}=$ joint alteration number, which represents the degree of alteration of the materials that form the faces. In accordance with Moore recommendations (USDA, 1997) $\mathrm{J}_{\mathrm{r}}$ was assumed 1 for intact rock and 2 or 3 for weathered rock ( 2 for shale of Bennett and Hughes Creek Zones C\&D formations, 3 for all the other rock units); $\mathrm{J}_{\mathrm{a}}$ was also 1 for intact rock and 2 to 4 for weathered limestone and 3 to 6 for shale, as shown in the last column of Table 1. Based on the same USDA recommendations, the ratio $J_{r, \max } / J_{a, \min }$ was associated with the intact (unweathered) rock and the ratio $\mathrm{J}_{\mathrm{r} \text {.min }} / \mathrm{J}_{\mathrm{a} \text {,max }}$ with the weathered rock. This way, through $\mathrm{K}_{\mathrm{d}}$ a range of $\mathrm{K}_{\mathrm{h}}$ was defined, with the maximum value for the intact rock and the minimum value for the weathered rock.

$\mathrm{J}_{\mathrm{s}}=$ relative ground structure number, which represents the orientation of the effective dip of the least favorable discontinuity with respect to stream flow. The number takes into account the effect of the relative shape of the material units (as determined by joint set spacings) on the ease with which the stream penetrates the ground and dislodges individual material units. For Tuttle Creek spillway $\mathrm{J}_{\mathrm{s}}=0.88$ was determined, based on the following parameters, approximately valid for all rock units: Spillway Flow Direction $=135$ azimuth degrees; Bedrock Strike $=330$ azimuth degrees; Bedrock Dip Direction $=240$ azimuth degrees; Rock Dip $=1$ degree .

\section{Flood Event and Erosion Monitoring}

Releases were gradually increased during a 4-day period until they reached the peak discharge at of $1700 \mathrm{~m}^{3} / \mathrm{s}$. Without any further change in gate opening, the discharge gradually decreased to zero during the following 17 days. An aerial photo at the end of releases is presented in Fig. 1 and the profile along the most eroded zone, before and after spillway releases, in Fig. 2. Fig. 3 shows the general view of the spillway during releases and soon after they stopped.

By comparing contours determined from aerial photos before and after the flow through the spillway, the total eroded distance along each headcut was 
determined. The measured erosion was defined as the horizontal distance along the middle of the hard layer at the top of the escarpment as illustrated in Fig. 4.

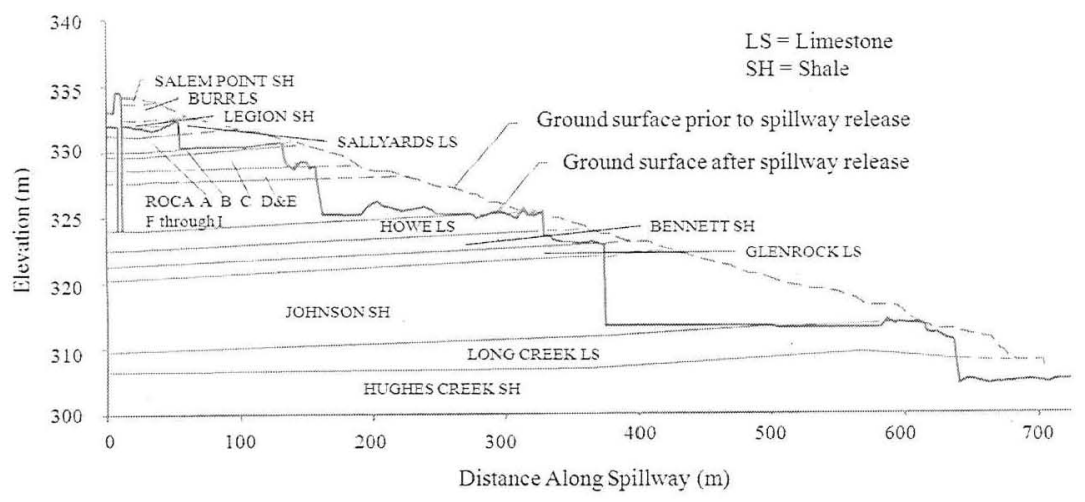

Figure 2. Profile along right side of Tuttle Creek spillway. (Both horizontal and vertical scales are in feet; 1 foot $=0.3048 \mathrm{~m}$ )
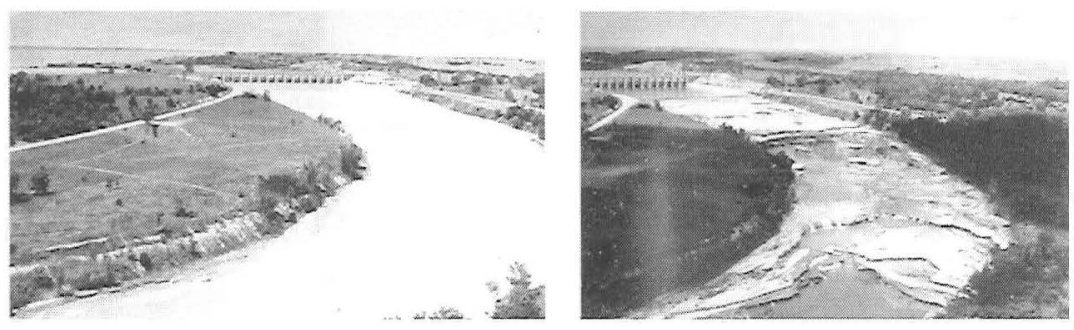

Figure 3. General view of Tuttle Creek spillway: left, during 1993 releases; right, immediately after releases stopped.

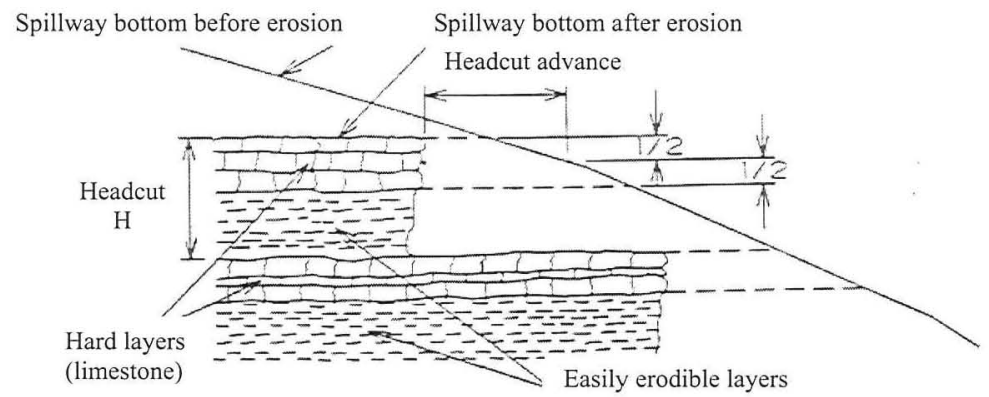

Figure 4. Scheme of spillway erosion. 
The headcut erosion was not uniform. The advance was relatively high at weak points and at other locations the erosion was minimal. All headcuts had a relatively hard layer (limestone) on top and easily erodible rock underneath. Fig. 5 presents a characteristic headcut, during and after releases.
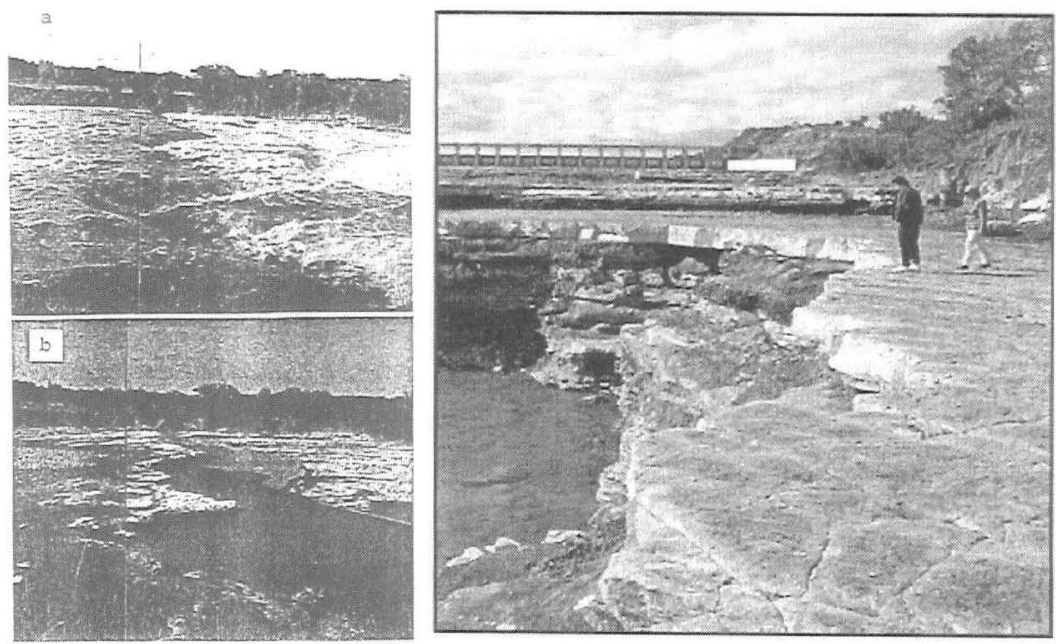

Figure 5. Headcuts 5, 6\&7: left: (a) during releases - 8/3/1993; (b) after releases -8/9/1993; right: one of the highest headcuts (view A on Fig. 1).

During the releases daily photographs were taken at nine different sites along the spillway, to document regression of headcuts. Based on these photos the erosion advance in the upstream direction was estimated at selected knick points on top of the headcuts, where the flow was visibly affected by the ledge. This method of estimating the erosion rate was somewhat inaccurate, but provided reasonable determination of average erosion rate for periods of time varying between 4 and 16 days. The estimation of average rates and associating them to the average unit discharge (as defined later) and to various degrees of rock weathering (shown in bold in Table 2) is illustrated in Fig. 6. See also Table 2 for corresponding data.

Early in the erosion process escarpments took shape, with hard (limestone) layers on top and soft (mostly shale) layers underneath. The aggregate headcut erodibility index was calculated with the formula (Temple and Moore, 1994):

where

$$
\mathrm{K}_{\mathrm{h}}=\exp \left[\Sigma \mathrm{h}_{\mathrm{i}} \ln \left(\mathrm{K}_{\mathrm{hi}}\right) /\left(\Sigma \mathrm{h}_{\mathrm{i}}\right)\right]
$$

$\mathrm{K}_{\mathrm{hi}}=$ Erodibility index of each rock unit exposed by the headcut;

$h_{i}=$ Thickness of each rock unit exposed by the headcut. 

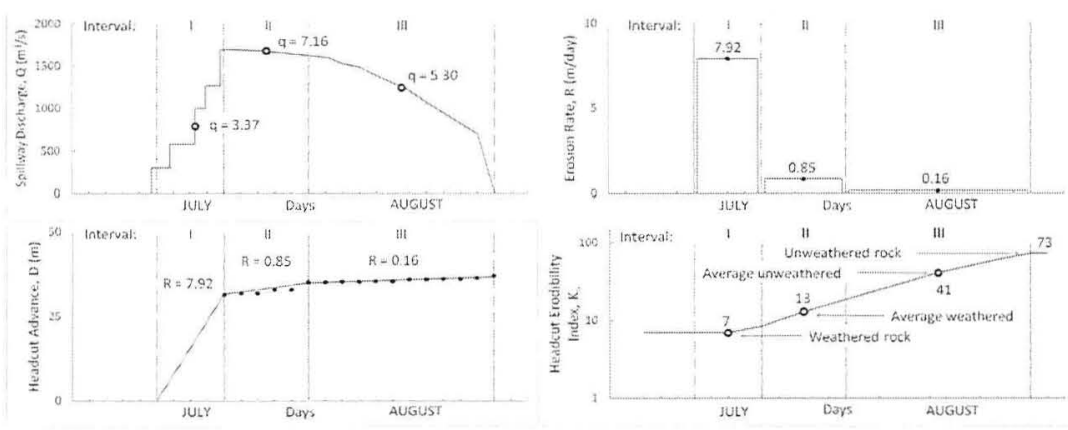

Figure 6. Headcut (No. 3) advance characterization per three time intervals: left - relating the average unit discharge, $q$ to average erosion rate, $R$; right relating the average erosion rate, $\mathrm{R}$ to the degree of rock weathering.

Table 2. Monitoring results and associated headcut characterization (in bold)

\begin{tabular}{|c|c|c|c|c|c|c|c|c|c|c|}
\hline \multirow{3}{*}{$\begin{array}{c}\text { Head- } \\
\text { cut } \\
\text { No. }\end{array}$} & \multicolumn{5}{|c|}{ Rate of Headcut Advance (m/day) } & \multicolumn{5}{|c|}{ Headcut Erodibility Index, $\mathbf{K}_{\mathrm{h}}$} \\
\hline & \multirow{2}{*}{$\begin{array}{c}\text { Initial } \\
1 \\
\end{array}$} & \multicolumn{3}{|c|}{ Intermediate } & \multirow{2}{*}{$\begin{array}{c}\text { Final } \\
5 \\
\end{array}$} & \multirow{2}{*}{$\begin{array}{c}\text { Initial } \\
6\end{array}$} & \multicolumn{3}{|c|}{ Intermediate } & \multirow{2}{*}{\begin{tabular}{|r|} 
Final \\
10
\end{tabular}} \\
\hline & & 2 & 3 & 4 & & & 7 & 8 & 9 & \\
\hline 1 & \multicolumn{5}{|c|}{ Not measured } & \multicolumn{5}{|c|}{ Layers completely washed out } \\
\hline 2 & 9.45 & & & 0.12 & & 10 & 17 & 30 & 53 & 95 \\
\hline 3 & 7.92 & 0.85 & & 0.16 & & 7 & 13 & 23 & 41 & 73 \\
\hline 4 & 12.2 & 9.94 & 1.22 & 0.37 & & 14 & 26 & 48 & 89 & 160 \\
\hline 5 & 4.72 & & & 0.06 & & 15 & 26 & 45 & 76 & 130 \\
\hline 6 & \multirow{2}{*}{\multicolumn{5}{|c|}{$\begin{array}{l}\text { Headcuts that were already } \\
\text { combined when monitoring started }\end{array}$}} & 15 & 27 & 47 & - & - \\
\hline 7 & & & & & & 8 & 14 & 26 & - & - \\
\hline $6+7$ & & 3.05 & & 1.58 & & 9 & 17 & 31 & 57 & 100 \\
\hline $8+9$ & \multicolumn{5}{|c|}{ Not measured } & 100 & 160 & 240 & 370 & 580 \\
\hline
\end{tabular}

Notes: The "initial" values of headcut $\mathrm{K}_{\mathrm{h}}$ (column 6) correspond to highly weathered rock and the "final" values (column 10) to the practically unweathered rock. Between them are "moderately weathered", "somewhat weathered", and "slightly weathered" (columns 7, 8, and 9) based on a logarithmic equation and that were correlated with corresponding rates of erosion (columns 2,3 , and 4 , respectively).

\section{Mathematical modeling of headcut advance}

The most comprehensive model of headcut advance at the time of Tuttle Creek spillway erosion event was that developed by Temple and Moore (published 1994). However, because that model was based mostly on spillways excavated in soil, it did not fit the data obtained from erosion monitoring at Tuttle Creek. Therefore, a site specific model was developed using Tuttle Creek data. In the development of the KCD (Kansas City District) model the general form of the USDA equation was assumed: 
where

$$
\mathrm{R}=\mathrm{C}\left[(\mathrm{qH})^{1 / 3}-\mathrm{T}^{1 / 3}\right]
$$

$\mathrm{R}=$ the rate of headcut advance in the upstream direction ( $\mathrm{m} /$ day);

$\mathrm{C}=$ parameter function of $\mathrm{K}_{\mathrm{h}}$;

$\mathrm{K}_{\mathrm{h}}=$ the aggregate headcut erodibility index; when a headcut downstream has a higher erosion rate than the headcut above it the two headcuts combine and $\mathrm{K}_{\mathrm{h}}$ changes accordingly;

$\mathrm{q}=\mathrm{Q} / \mathrm{L}=$ unit discharge, the volume of flow over the headcut per units of width and time $\left(\mathrm{m}^{3} / \mathrm{s} / \mathrm{m}\right)$; $\mathrm{Q}$ is the spillway discharge and $\mathrm{L}$ the length of the headcut, which may change significantly due to uneven erosion across the spillway;

$\mathrm{H}=$ the drop in the energy grade line as the flow passes over the headcut, approximately equal to the headcut height $(\mathrm{m})$; it changes when two or more headcuts combine due to their different rate of advance;

$\mathrm{T}=$ threshold energy required to generate headcut advance.

First the threshold $\mathrm{T}$ was determined based on observed discharges that did not induce significant erosion; after that $\mathrm{C}$ was estimated based on data in Table 2:

$$
R(\mathrm{~m} / \text { day })=\exp \left[3.77-0.57 \ln \left(\mathrm{K}_{\mathrm{h}}\right)\right] \cdot\left[(\mathrm{qH})^{1 / 3}-0.361\left(\mathrm{~K}_{\mathrm{h}}\right)^{1 / 2.25}\right]
$$

Details of the model derivation are presented elsewhere (Perlea and al., 1997).

\section{Benefits of KCD spillway erosion model}

The model was used by the KCD to evaluate the potential breach of the spillway during future flood events. Parametric studies included:

- Various types of discharge hydrographs, including the 1993 discharge hydrograph and the design outflow hydrograph;

- Different longitudinal profiles along the eroded spillway, including a regraded profile to minimize initial concentration of flow;

- Two variants with respect to degree of weathering: (1) unweathered rock, condition believed to occur immediately after 1993 erosion; and (2) weathering to approximately the same extent as existed before the 1993 event, i.e. after decades of exposure to atmospheric weathering factors.

It was concluded that the spillway can likely withstand the spillway design flood (peak discharge of $17320 \mathrm{~m}^{3} / \mathrm{s}$ ) without loss of the concrete weir structure caused by erosion of the unlined chute. Long duration low flow events may represent more significant risk than the spillway design event. However, the erosion model indicated that a continuous flow of $1420 \mathrm{~m}^{3} / \mathrm{s}$, similar to that of 1993 , could threaten the weir structure only after a duration of 50 to 70 days, depending on the extent of rock weathering in the unlined chute. Such an event would be extremely rare.

These findings provided increased confidence in the expected future performance of the spillway and led to the design of a quite economical interim repair, based on protection of the rock for preventing weathering and preventing concentration of flow at the beginning of a future flood event by filling the existing knick points with grouted rock fill. A description of the spillway repair is published elsewhere (Mathews et al., 1998). 


\section{ATTEMPTS OF GENERALIZATION OF KCD MODEL}

Attempts to apply the KCD erosion model to other documented case histories failed. The few USDA cases for spillways cut in rock had the erosion rate significantly overestimated. However, in the case of the Saylorville spillway, most of the observed erosion rates were significantly larger than predicted, even though the model had been conceived to overpredict erosion rates.

The KCD model was modified by the USACE Engineer Research and Development Center (ERDC), as presented in USSD, 2006. ERDC considered more observation records, in an attempt to generalize the model. Like the KCD model, the ERDC model still overpredicts rates included in USDA bank of data but severely underpredicts Saylorville spillway erosion rates; in addition, the ERDC model underpredicts the Tuttle Creek data.

It is believed that a major aspect that makes a general model difficult to create is that an average discharge and an average erosion index do not adequately represent the erosion process. In addition the rock mass parameters which lead to the erosion index are usually subjective and widely variable. However it is believed that a credible site-specific model, useful for design, can be developed.

\section{CONCLUSIONS}

The currently available data does not allow preparation of a suitably reliable general model for sedimentary rock erosion. Existing models, when used, must be used with caution and considerable judgment. Fortunately, with attention to available spillway design criteria (Walberg et al 1995) there is a very low probability for the first release to be catastrophic, thus there is usually an opportunity to develop a site specific model for spillway rehabilitation design, similar to the KCD model presented in this paper.

\section{REFERENCES}

Kirsten, H.A.D. (1982). "A Classification System for Excavation in Natural Materials." Civil Engineer in South Africa, Vol.24, No.7 (July): 293-308.

Mathews, D.L., Perlea, V.G., Walberg, F.C., and Anderson, D.R. (1998). "Erosion and Repair of Unlined Spillway Chute Excavated in Rock." Fourth Int. Conf. on Case Hist. in Geotech. Engrg, St. Louis, MO, USA, Paper No. 6-05.

Moore, J.S., Temple D.M., and Kirsten, H.A.D. (1994). "Headcut Advance Threshold in Earth Spillways.” Bull. Assoc. Engineering Geologists, Vol. XXXI, No. 2.

Perlea, V.G., Mathews, D.L., and Walberg, F.C. (1997). "Rock Erosion of Unlined Spillway Chute." $19^{\text {th }}$ Congress on Large Dams, Florence, Italy: 153-172.

Temple, D.M. and Moore, J.S. (1994). "Headcut Advance Prediction for Earth Spillways." Am. Soc. Agr. Engrs., Paper No. 942540, presented at the 1994 ASAE International Summer Meeting, Spocane, Washingon, USA.

USDA (1997). "Field Procedures Guide for the Headcut Erodibility Index." Chapter 52, Part 628 Dams, Nat. Engrg Handbook, 210-VI-NEH, rev. 1, 2001, 33 p.

USSD (2006). "Erosion of Unlined Spillways." Prepared by U.S. Society on Dams, Committee on Hydraulics of Dams, Denver, CO, 183 p.

Walberg, F.C., Mathews, D., Hoyt, J., Huffman, C., and Dridge, R., (1995) USCOLD, $15^{\text {th }}$ Annual Meeting and Lecture: 113-131. 